\title{
Plant growth regulators optimization for maximize shoots number in Agave americana L. by indirect organogenesis
}

\section{Optimización de los reguladores de crecimiento para maximizar el número de brotes en Agave americana L. por organogénesis indirecta}

\author{
Sheila Jazmín Reyes-Zambrano ${ }^{1}$, Carlos Alberto Lecona-Guzmán ${ }^{1}$, Felipe Alonso Barredo-Pool², \\ José Dolores Ambrosio Calderón ${ }^{3}$, Miguel Abud-Archila ${ }^{1}$, Reiner Rincón-Rosales ${ }^{1}$, Víctor \\ Manuel Ruiz-Valdiviezo ${ }^{1}$ \& Federico Antonio GutiérRez-Miceli ${ }^{1 *}$ \\ ${ }^{1}$ Tecnológico Nacional de México, Instituto Tecnológico de Tuxtla-Gutiérrez, Tuxtla-Gutiérrez, México. Carretera Panaméricana \\ km 1080, CP 29050, Chiapas, México. \\ ${ }^{2}$ Unidad de Biotecnología Centro de Investigación Científica de Yucatán. Calle $43 \mathrm{~N}^{\circ} 130$, Colonia Chuburná de Hidalgo, CP. \\ 97200, Mérida, Yucatán, México. \\ ${ }^{3}$ Departamento de Ciencias Básicas. Instituto Tecnológico de Tizimín. Final Aeropuerto Cupul s/n, C.P. 97700, Tizimín, \\ Yucatán, México. \\ *fgmiceli@gmail.com
}

\begin{abstract}
Current protocols for Agave americana L. micropropagation have limited commercial application due to the low number of plants produced by explant. Indirect organogenesis could be an alternative, however is necessary to optimize plant growth regulators for plantlet number maximization. The objective of this work was to optimize 2,4-dicholorophenoxyacetic acid (2,4-D) and 6-benzyl adenine (BA) concentrations on the induction of $A$. americana embryogenic callus from apical meristem as explant for maximized the number of shoots per callus using a response surface experimental design. MS medium containing $30 \mathrm{~g} \mathrm{l}^{-1}$ sucrose amended with $0.11,0.18,0.45$ or $2.26 \mu \mathrm{M} 2,4-\mathrm{D}$, and 11.0, 22.0, 38.2 or $44.0 \mu \mathrm{M}$ BA was used. Nine treatments with three repetitions was applied and number of shoots per callus were monitored after 4,16 , 20 and 36 weeks. In vitro rooting of shoot was done in MS medium added with indole butyric acid (IBA). A maximum number of plantlets per explant (74) was obtained with $2.26 \mu \mathrm{M}$ of 2,4-D and $38.2 \mu \mathrm{M}$ BA. In conclusion, the indirect organogenesis of $A$. americana L. could be an alternative for obtain plantlets for propagation commercial purposes.
\end{abstract}

KEYwORDS: 6-benzyl adenine; 2, 4-dicholorophenoxyacetic acid; callus induction; indole butyric acid.

\begin{abstract}
RESUMEN
Los protocolos actuales para la micropropagación de Agave americana L. tienen limitaciones para su aplicación comercial debido al bajo número de plantas producidas por cada explante. La organogénesis indirecta podría ser una alternativa, sin embargo, es necesario optimizar los reguladores de crecimiento vegetal para maximizar el número de plantas. El objetivo del trabajo fue optimizar la concentración de ácido 2,4-diclorofenoxiacetico (2,4-D) y de 6-bencil adenina (BA) sobre la inducción de callos embriogénicos en $A$. americana usando meristemos apicales como explante para maximizar el número de brotes por callo, utilizando un diseño experimental de superficie de respuesta. Se utilizó el medio Murashige Skoog (MS) adicionado con $30 \mathrm{~g} \mathrm{l}^{-1}$ de sacarosa, y con 0,$11 ; 0,18 ; 0,45$ o 2,26 $\mu \mathrm{M}$ de 2,4-D, y 11,0; 22,0; 38,2 o 44,0 $\mu \mathrm{M}$ de BA. Se implementaron 9 tratamientos con 3 repeticiones y el número de brotes por callo fue evaluado después de $4,16,20$ y 36 semanas. Se indujo el enraizamiento in vitro usando medio MS adicionado con ácido indolbutírico (AIB). Se obtuvo un máximo de 74 plántulas por callo, usando $2,26 \mu \mathrm{M}$ de 2,4-D y $38,2 \mu \mathrm{M}$ de BA. En conclusión, la organogénesis indirecta podría ser una alternativa para la micropropagación de $A$. americana $\mathrm{L}$ con fines comerciales.
\end{abstract}

Palabras clave: 6-bencil adenina; ácido 2, 4-diclorofenoxiacético; inducción de callos; ácido indolbutírico.

\section{INTRODUCTION}

All species of the family Agavaceae are native to America and are classified in eight genera. It is assumed that $75 \%$ of all species belonging to the Agavaceae family are found in
Mexico with 55\% being endemic. The genus Agave belonging to the family Agavaceae, arose approximately 15 million years ago (Rocha et al. 2005). Agave tissue culture research has been mainly developed for mass propagation purposes in different species such as $A$. fourcroydes Lem. (Robert et 
al. 1987), A. cantala (Hawk.) Roxb. ex Salm-Dyck (Binh et al. 1990), A. parrasana A. Berger (Santacruz-Ruvalcaba et al. 1999), A victoria-reginae T. Moore (Rodríguez-Garay et al. 1996, Martínez-Palacios et al. 2003), A. sisalana Perrine ex Engelm. (Nikam 1997, Hazra et al. 2002, Nikam et al. 2003 ) and A. tequilana F.A.C. Weber (Castro-Concha et al. 1990, Robert et al. 1992). All of these regeneration systems are different due to species-specific responses.

Although Agave americana L. is not yet a "threatened" species in Mexico, its distribution has been reduced as its natural habitat is decreasing as a result of explotation, especially in southern Mexico. A. americana is used for textile fibre production (Hamissa et al. 2007) and has been used in traditional medicine as natural defaunating agent in animals as the leaves contain high concentrations of saponins (Nasri \& Salem 2012). Tinto et al. (2005) reported the isolation of a new homoisoflavonoid from $A$. americana leaves. Eight steroidal compounds, including three new hecogenin glycosides, were isolated from fermented A. americana leaves (Jian-Ming et al. 2003). In Chiapas (Mexico), A. americana has been cultivated for the production of "comiteco" a local alcoholic beverage. Multiplication of $A$. americana occurs through tillers and seed germination, but its propagation rate is low in its natural environment (Illsley et al. 2004).

Callus culture might be a useful technique to produce plants of the desired clone and might also serve as a starting point for future plant improvement through molecular biotechnology in $A$. americana Recently, Chen et al. (2014) have been reported a protocol for A. americana micropropagation, however maximum shoot number was 18/explant after 4 weeks and therefore it is necessary to increase the shoots number for improvement the commercial application of these protocol. Agave species require specific concentrations and combinations of plant growth regulators to obtain an efficient protocol for plant regeneration (Infante et al. 2003, Garriga et al. 2010).

Response surface methodology (RSM) is a collection of mathematical and statistical techniques for designing experiments, building models, evaluating the significant relative of several independent variables and determining optimum conditions for desirable responses approach have been applied for optimization and process modelling (Bezerra et al. 2008). The development of an optimum procedure to improve the callus conversion to somatic embryos will reduce the plant production costs and improve the multiplication rate.

In this study, the effect of different concentrations of 2,4-dicholorophenoxyacetic acid (2,4-D) and 6-benzyl adenine (BA) on the induction of $A$. americana callus from meristem were optimized for maximized the number of shoots per callus using a surface experimental design. Plantlets were in vitro rooting with indole butyric acid (IBA) so that complete plantlets were obtained.

\section{MATERIALS AND METHODS}

\section{Plant material AND Disinfection}

The $A$. americana plants used in this study were obtained from a collection at the experimental site of Tuleaito located in Comitan (NL 16 $6^{\circ} 15^{\prime} 04^{\prime}$, WL 92 ${ }^{\circ} 08^{\prime} 03^{\prime \prime}$ ) at an altitude of $1622 \mathrm{~m}$ a.s.1. (Chiapas, México). Shoot apical meristems were excised from plants and washed and submerged in $0.5 \%$ agrimicin $500^{\circledR}$ solution mixed with $0.5 \%$ captan $^{\circledR}$ for $20 \mathrm{~min}$, rinsed three times with sterile distilled water, immersed in $70 \%$ ethanol for $5 \mathrm{~min}$ and in a $40 \%(\mathrm{w} / \mathrm{v})$, Sodium hypochlorite $(\mathrm{NaClO})$ solution $(2.5 \%)$ for $20 \mathrm{~min}$, and rinsed two times with sterile distilled water.

INDUCTION OF CALLUS

Disinfected meristems were placed on a MS medium (Murashige \& Skoog 1962) containing $30 \mathrm{~g} \mathrm{l}^{-1}$ sucrose and $2.5 \mathrm{~g} \mathrm{l}^{-1}$ phytagel, with $0.11,0.18,0.45$ or $2.26 \mu \mathrm{M}$ 2,4-D, and $11.0,22.0,38.2$ or $44.0 \mu \mathrm{M}$ BA. The culture media were adjusted to $\mathrm{pH} 5.8$ with $0.1 \mathrm{~N} \mathrm{NaOH}$ before being autoclaved at $121{ }^{\circ} \mathrm{C}$ under a pressure of $1.2 \mathrm{~kg} \mathrm{~cm}^{-2}$ for $15 \mathrm{~min}$. Percentage of explants producing callus were recorded one month after culture initiation without subculturing. Each experiment was repeated five times with at least 10 explants. Callus were isolated from the explants and transferred to flasks, each containing $30 \mathrm{ml}$ fresh medium. They were sub-cultured monthly under the same conditions.

\section{HistologicAl ANALYSIS}

The morphogenic pathway for regeneration and the origin of the structures formed in vitro were determined in regenerated callus using a scanning electron microscope. Callus were removed from the phytagel and washed several times with $0.1 \mathrm{M}$ phosphate buffer $\mathrm{pH}$ 6.0. They were fixed in $5 \%$ glutaraldehyde, mixed with $0.1 \mathrm{M} \mathrm{pH} 7.0$ phosphate buffer for $2 \mathrm{~h}$, rinsed two times in $0.1 \mathrm{M}$ phosphate buffer $(\mathrm{pH} 7.0$ ), fixed again with $1 \%$ osmium tetraoxide and rinsed two times with distilled water. Dehydration was done in increasing solutions of ethanol $(30,50,70,90$, and $100 \%$ ) with submerging in each solution for $1 \mathrm{~h}$. The drying was done at the critical point of $\mathrm{CO}_{2}$, which is an established method for dehydrating biological tissue prior to examination with a Scanning Electron Microscope. The dried samples were metalized with a $21 \mathrm{~nm}$ thick gold cover using a Denton Vacuum Desk II metalizer. The metalized samples were observed in high vacuum at $8 \mathrm{kV}$ accelerating voltage, and a distance of $15 \mathrm{~mm}$ under a TOPCON SM510 scanning electron microscope (SEM).

\section{SHOOT REGENERATION}

Callus clusters were transferred to media consisting of MS medium without regulators, $30 \mathrm{~g} \mathrm{l}^{-1}$ sucrose and 2.5 $\mathrm{g} \mathrm{l}^{-1}$ phytagel. Cultures were maintained at $25{ }^{\circ} \mathrm{C}$ under continuous illumination $\left(35 \mathrm{mmolm}^{2} \mathrm{~s}^{-1}\right)$ with fluorescent 
lights. Percentage of callus clusters forming shoots was determined two months after transfer to shoot induction media without sub-culturing. Regenerated shoots were excised from the callus and transferred to test tubes $(25 \mathrm{x}$ $130 \mathrm{~mm}$ ) each containing $10 \mathrm{ml}$ half-strength MS medium containing $30 \mathrm{~g} \mathrm{l}^{-1}$ sucrose and $2 \mathrm{~g} \mathrm{l}^{-1}$ phytagel. Cultures were maintained at $25^{\circ} \mathrm{C}$ under continuous illumination (35 $\mathrm{mmol} \mathrm{m} \mathrm{m}^{-2} \mathrm{~s}^{-1}$.

\section{ROOTING AND ACCLIMATIZATION OF PLANTLETS}

For in vitro rooting, Plantlets were placed in MS medium with IBA for root induction (Table II). The number of roots and auxiliary roots, and root length was determined after 4 and 11 weeks. Plantlets with a well-developed root system were washed in running water to remove phytagel and transferred to unicel pots $(12 \times 10 \mathrm{~cm})$ containing peat moss and agrolite mixture (1:1) for acclimatization. Plantlets were grown in the greenhouse with temperatures that increased from $18 \pm 2{ }^{\circ} \mathrm{C}$ for 4 weeks to $20-26{ }^{\circ} \mathrm{C}$ for eight weeks. Plants were transferred to near-commercial greenhouse conditions. Temperatures fluctuated between $30-35{ }^{\circ} \mathrm{C}$ in daytime and $16-24^{\circ} \mathrm{C}$ at night.
DATA ANALYSIS

Explant with callus percent, number of shoots per callus, root number, number of axillary roots and root length data were subjected to a one-way analysis of variance to test for significant difference between the treatments. The Statgraphic Plus Software (1999) was used for the regression analysis of the experimental data obtained. The quality of the fit of the model was expressed by the coefficient of determination $\mathrm{R}^{2}$ and its statistical significance checked by an F-test. The significance of the regression coefficient was tested by a t-test. The level of significance was $p<0.05$. A differential calculation method was then used to predict the optimum.

\section{RESULTS}

Callus induction

The percentage of explants with callus was affected significantly by the different combinations of 2,4-D and BA and varied from $20 \%$ in treatments 7 and 11 to 100 $\%$ in the 2, 4 and 15 treatments $(p<0.05)$ (Table I). Higher concentration $(44.0 \mu \mathrm{M})$ of Bencyl adenine (BA) affected negatively the callus induction percentage (Fig. 1b).

TABLE I. Experimental design to evaluate the effect of 2,4-Dicholorophenoxyacetic Acid (2,4-D) and 6-Benzyladenine (BA) on explants with callus percentage and the number of shoots per callus of Agave americana $\mathrm{L}$.

TABLA I. Diseño experimental para evaluar el efecto del ácido 2,4-Diclorofenoxiacético (2,4-D) y 6-Benziladenina (BA) sobre el porcentaje de explantes con callos y el número de brotes por callo de Agave americana L.

\begin{tabular}{|c|c|c|c|c|c|c|c|}
\hline \multirow{3}{*}{ TREATMENT } & & & \multirow{3}{*}{$\begin{array}{c}\text { EXPLANT } \\
\text { WITH CALLUS } \\
(\%)\end{array}$} & \multicolumn{4}{|c|}{ NumBER OF SHOOTS PER CALLUS } \\
\hline & $2,4-\mathrm{D}$ & BA & & 4 & 16 & 20 & 36 \\
\hline & \multicolumn{2}{|c|}{$(\mu \mathrm{M})$} & & \multicolumn{4}{|c|}{ (weeks) } \\
\hline 1 & 0.11 & 11.0 & 80 & $1.2 \mathrm{~b}$ & $10.0 \mathrm{~b}$ & $19.2 \mathrm{~b}$ & $98 \mathrm{a}$ \\
\hline 2 & 2.26 & 11.0 & 100 & $0.2 b$ & $0.0 \mathrm{c}$ & $0.0 \mathrm{c}$ & $0.0 \mathrm{~b}$ \\
\hline 3 & 0.11 & 44.0 & 80 & $7.6 \mathrm{a}$ & $18.8 \mathrm{a}$ & $39 \mathrm{a}$ & $194.0 \mathrm{a}$ \\
\hline 4 & 2.26 & 44.0 & 100 & $0.0 \mathrm{~b}$ & $0.0 \mathrm{c}$ & $0.0 \mathrm{c}$ & $0.0 \mathrm{~b}$ \\
\hline 5 & 0.18 & 22.0 & 40 & $0.2 \mathrm{~b}$ & $3.0 \mathrm{c}$ & $4.6 \mathrm{c}$ & $46.8 \mathrm{ab}$ \\
\hline 6 & 0.45 & 22.0 & 40 & $0.0 \mathrm{~b}$ & $0.2 \mathrm{c}$ & $2.8 \mathrm{c}$ & $56.2 \mathrm{ab}$ \\
\hline 7 & 0.18 & 38.2 & 20 & $0.0 \mathrm{~b}$ & $0.0 \mathrm{c}$ & $0.0 \mathrm{c}$ & $32.6 \mathrm{ab}$ \\
\hline 8 & 0.45 & 38.2 & 60 & $0.0 \mathrm{~b}$ & $0.0 \mathrm{c}$ & $0.0 \mathrm{c}$ & $8.0 \mathrm{~b}$ \\
\hline 9 & 0.11 & 22.0 & 60 & $0.6 \mathrm{~b}$ & $0.0 \mathrm{c}$ & $2.0 \mathrm{c}$ & $21.4 \mathrm{ab}$ \\
\hline 10 & 0.11 & 38.2 & 60 & $0.0 \mathrm{~b}$ & $0.0 \mathrm{c}$ & $0.4 \mathrm{c}$ & $27.2 \mathrm{ab}$ \\
\hline 11 & 0.18 & 11.0 & 20 & $0.0 \mathrm{~b}$ & $0.0 \mathrm{c}$ & $3.6 \mathrm{c}$ & $20.2 \mathrm{~b}$ \\
\hline 12 & 0.18 & 44.0 & 80 & $0.0 \mathrm{~b}$ & $0.0 \mathrm{c}$ & $1.2 \mathrm{c}$ & $10.0 \mathrm{~b}$ \\
\hline 13 & 0.45 & 11.0 & 40 & $1.8 \mathrm{~b}$ & $13.8 \mathrm{c}$ & $4.2 \mathrm{c}$ & $9.2 \mathrm{~b}$ \\
\hline 14 & 0.45 & 44.0 & 60 & $0.0 \mathrm{~b}$ & $0.0 \mathrm{c}$ & $0.0 \mathrm{c}$ & $12.0 \mathrm{~b}$ \\
\hline 15 & 2.26 & 38.2 & 100 & $0.0 \mathrm{~b}$ & $0.0 \mathrm{c}$ & $0.0 \mathrm{c}$ & $0.0 \mathrm{~b}$ \\
\hline
\end{tabular}


Indirect organogenesis of Agave americana: ReYES-ZAMBRANO, S.J. ET AL.

TABLE II. Effect of Indol Butyric Acid (IBA) on rooting of Agave americana L. plantlets grown in MS medium.

TABLA II. Efecto del ácido indolbutírico (IBA) en la formación de raíces de Agave americana L. plántulas cultivadas en medio MS.

\begin{tabular}{cccccc}
\hline IBA & \multicolumn{2}{c}{ Number of Roots } & \multicolumn{2}{c}{ Number OF AXILlary Roots } & Root length \\
$(\mu \mathrm{M})$ & 4 weeks & 11 weeks & 4 weeks & 11 weeks & $(\mathrm{cm})$ \\
\hline 0 & $0.9 \mathrm{a}^{\mathrm{a}}$ & $2.0 \mathrm{a}$ & $0.8 \mathrm{a}$ & $2.3 \mathrm{a}$ & $3.8 \mathrm{a}$ \\
4.9 & $0.6 \mathrm{a}$ & $2.3 \mathrm{a}$ & $1.6 \mathrm{a}$ & $3.3 \mathrm{a}$ & $3.7 \mathrm{a}$ \\
14.0 & $1.4 \mathrm{a}$ & $2.5 \mathrm{a}$ & $0.5 \mathrm{a}$ & $1.4 \mathrm{a}$ & $3.3 \mathrm{a}$ \\
24.6 & $1.6 \mathrm{a}$ & $1.6 \mathrm{a}$ & $0.0 \mathrm{a}$ & $0.5 \mathrm{a}$ & $3.0 \mathrm{a}$ \\
LSD $(0.05)^{\mathrm{b}}$ & 2.1 & 2.5 & 1.7 & 3.3 & 1.5 \\
\hline
\end{tabular}

a Values with the same letter are not significantly different between the treatments, ${ }^{\mathrm{b}}$ LSD: Least Significant Difference $(P<0.05) . /{ }^{\text {a }}$ Valores con la misma letra no hay diferencia estadística significativa entre tratamientos, ${ }^{\mathrm{b}}$ LSD: Diferencia Mínima Significativa $(P<0,05)$.
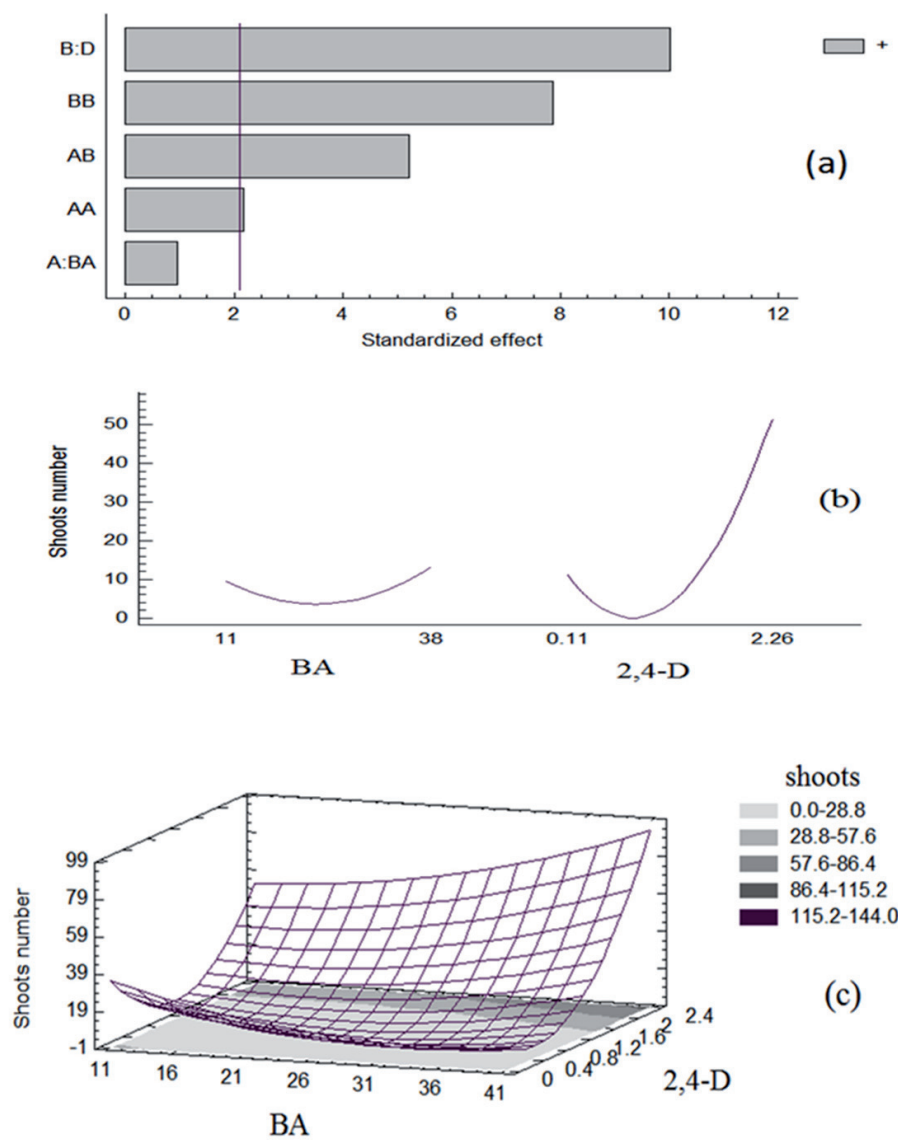

Figure 1. (a) Standardized Pareto chart to investigate the effect of 6-Benzyladenine (A) and 2, 4-Dicholorophenoxyacetic Acid (B); (b) Main effect of 6-Benzyladenine and 2, 4-Dicholorophenoxyacetic Acid on shoots number in A. americana (c) Surface response plot showing the relative effect of 6-Benzyladenine and 2, 4-Dicholorophenoxyacetic Acid on shoots number in A. americana. AB is the interaction between 6-Benzyladenine and 2, 4-Dicholorophenoxyacetic Acid; AA is the quadratic term for 6-Benzyladenine; BB is the quadratic term for 2, 4-Dicholorophenoxyacetic Acid, on shoots number of Agave americana.

Figura 1. (a) Gráfica de Pareto estandarizada para investigar el efecto de la 6-Benciladenina (A) y del Ácido 2, 4-Diclorofenoxiacético (B); (b) Efectos principales de la 6- Benciladenina y del Ácido 2, 4-Dicholorofenoxiacético sobre el número de brotes en $A$. americana; (c) Gráfica de superficie de respuesta que muestra el efecto relativo de la 6-Benciladenina en combinación con el Ácido 2, 4-Dicholorofenoxiacético sobre el número de brotes en A. americana. $\mathrm{AB}$ es el término que denota la interacción entre la 6- Benciladenina y el Ácido 2, 4-Dicholorofenoxiacético; AA es el término cuadrático para la 6- Benciladenina; BB es el término cuadrático para el Ácido 2, 4-Dicholorofenoxiacético, sobre el número de brotes en Agave americana. 
SHOOT INDUCTION

The number of shoots per callus obtained in four weeks varied from 0 in treatments 4, 6, 7, 8, 9, 10, 11, 12, 14 and 15 to 7.6 in treatment 3 (Table I). Treatment 3 contained 0.45 $\mu \mathrm{M}$ 2,4-D (the lower concentration) supplemented with 44.0 $\mu \mathrm{M}$ BA (the higher concentration). After four weeks, the number of shoots was higher in callus with $44 \mu \mathrm{M}$ BA and $0.11 \mu \mathrm{M} 2,4-\mathrm{D}$ than in the other treatments (Fig. 2A-B). In callus cultivated for 16 and 20 weeks, the number of shoots was higher in callus with $44 \mu \mathrm{M}$ BA and $0.11 \mu \mathrm{M} 2,4-\mathrm{D}$ than in the other treatments (Table I). Quadratic model was suggested for shoot number optimization in function of BA and 2,4-D. Signifficative factors were 2,4-D, quadratic term of 2,4-D, BA-2,4-D interaction and quadratic term of BA (Fig. 1a). Individual effects of BA and 2,4-D indicated that a higher concentration of 2,4-D promoted a more number of shoots per callus (Fig. 1b). According the surface response graph (Fig. 1c), maximum value for shoot number (74) per callus was obtained with $38,0 \mu \mathrm{M}$ BA plus $2.26 \mu \mathrm{M} 2,4-\mathrm{D}$. Mathematical model for shoot number is:

$$
\begin{aligned}
& \mathrm{SH}=62.3-2.96(\mathrm{BA})-59.57(2,4-\mathrm{D})+0.042\left(\mathrm{BA}^{2}\right)+0.89 \\
& (\mathrm{BA})(2,4-\mathrm{D})+23.89\left(2,4-\mathrm{D}^{2}\right)
\end{aligned}
$$

\author{
$\mathrm{SH}=$ Shoot number; $\mathrm{BA}=$ Bencyl Adenine; 2,4-D \\ $=2,4$-Dichorophenoxyacetic Acid; $\mathrm{R}^{2}=0.92$
}

Histological anAlysis

Histological analysis in callus induced with $44.0 \mu \mathrm{M}$ BA + $0.11 \mu \mathrm{M}$ 2,4-D from Agave americana confirm the presence of meristematic structures, which when divided by mitosis led to adventitious shoots (Fig. 3). Meristematic zones with high mitotic activity were observed (Fig. 3B) to divide these cells gave rise to new structures. Also the formation of vascular bundles (Fig. 3C) which showed connection with maternal tissue was observed indicating that the process is an indirect organogenesis (Fig. 3D). The organogenic centers were observed to have a very similar to the meristem of an axillary bud appearance.

\section{ROOT INDUCTION}

The number of roots was not affected by the IBA concentration (Table II). The number of axillary roots and root length also was not affected by IBA concentration (Fig 2C). All plantlets in the acclimatization step survived without apparent phenotypic changes in comparison with original plants (Fig 2D).

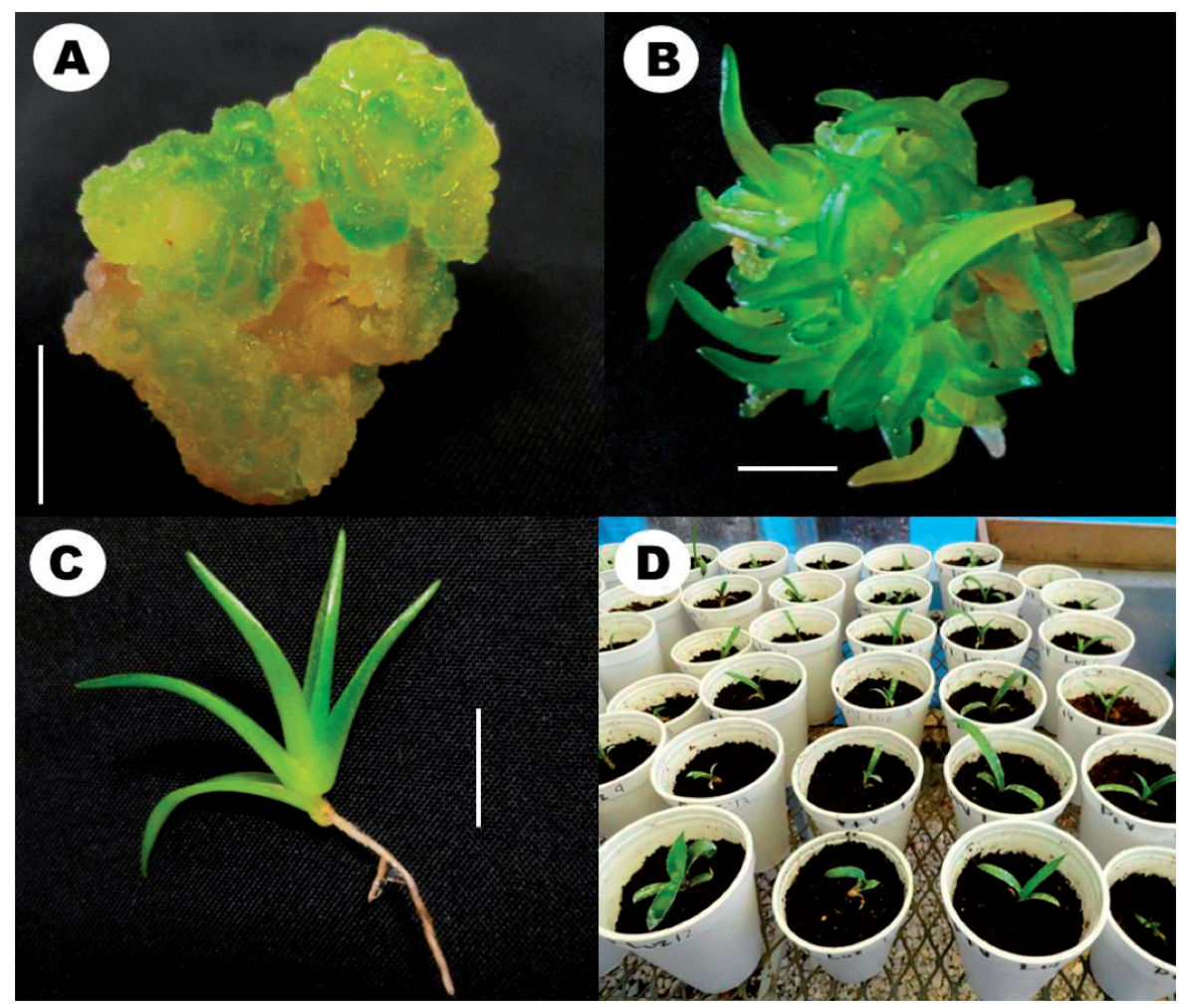

Figure 2. Indirect organogenesis of Agave americana L. (A) Callus induced from meristematic tissue; (B) Adventitious bud formation from callus; (C) Plantlets with roots after Indol Butyric Acid treatment and (D) acclimatized plants. Bar corresponds to $2.0 \mathrm{~cm}$.

Figura 2. Organogénesis indirecta de Agave americana L. A) Callo inducido a partir de tejido meristemático; B) Formación de brotes adventicios a partir de callos; C) Plántulas con raíces después del tratamiento con ácido indolbutírico; D) Plantas aclimatadas. Barra corresponde a $2,0 \mathrm{~cm}$. 


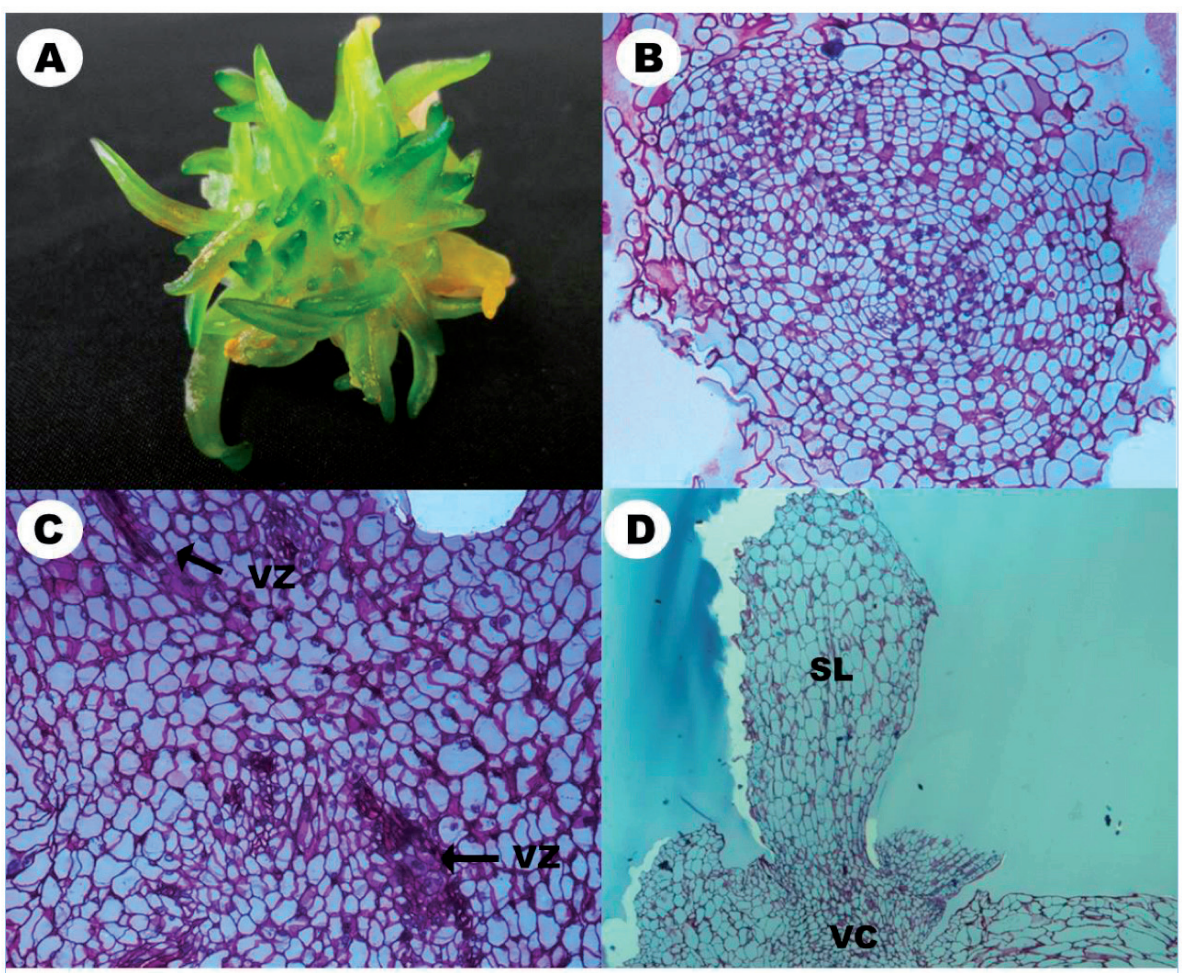

FiguRE 3. Histological analysis of Agave americana callus. (A) Cluster callus; (B) Accumulation of cells with high mitotic activity in callus; (C) Callus transversal cross-section with vascular tissues within callus; (D) Accumulation of cells that are the starting point for the formation of shoots. VZ, vascular zone; VC, vascular connection; SL, Sheath leaves.

Figura 3. Análisis histológico de callos de Agave americana. A) Callo inducido; B) Acumulación de células con alta actividad mitótica en los callos; C) Sección transversal del callo con tejido vascular en el callo; D) Células que inician la formación de brotes. VZ, zona vascular; $\mathrm{VC}$, conexión vascular; SL, hoja del brote.

\section{DISCUSSION}

The effect of 2,4-D was evident, embryogenic callus induction increased with increasing 2,4-D concentration (Table II). An efficient production of high-quality callus is a prerequisite to achieve efficient plant regeneration via indirect organogenesis (Zhang et al. 2004). Several studies with in vitro organogenesis reported that the critical factor was the plant growth regulators. Meratan et al. (2009) reported a maximum growth of callus of Acanthophyllum sordidum Bunge ex Boiss, a medicinally plant from Iran, with the most efficient regeneration of shoots and roots when $2.69 \mu \mathrm{M}$ 1-naphthalene acetic acid (NAA), $2.69 \mu \mathrm{M}$ $\mathrm{NAA}+4.54 \mu \mathrm{M}$ thidiazuron and $2.46 \mu \mathrm{M}$ IBA were used. Our results are similar to those reported by Robert et al. (1987) since using $0.11 \mu \mathrm{M}$ of 2,4-D obtained callus in $A$. sisalana. Numerous studies have shown that 2,4-D induces somatic embryogenesis in many plant species (Aviles-Viñas et al. 2012, Portillo et al. 2007, Santana-Buzzy et al. 2009, Zapata-Castillo et al. 2007, Zuo et al. 2002). However, the 2,4-D concentration used is a critical factor. Studies with
Valencia sweet orange (Citrus sinensis L.) showed that the somatic embryogenesis decreased when the concentration of 2,4-D increased and it was fully inhibited with 27.1 $\mu \mathrm{M}$ 2,4-D (Pan et al. 2010). To explain the effect of 2,4$\mathrm{D}$ on embryogenic callus induction in Agave americana is necessary genetic studies and most likely LEC/FUS genes may be involved. Studies with Arabidopsis thaliana (L.) Heynh. have been demonstrated that LEC/FUS genes are essential for in vitro somatic embryogenesis induction and this results was indicated auxin accumulation was rapid in all tissues of the explants. This observation suggests that loss of embryogenic potential in the lec 2 mutant in vitro is not related to the distribution of exogenously applied 2,4-D (Gaj et al. 2005).

The indirect organogenesis from callus culture was successful and complete plants without apparent somaclonal variations were obtained after three months (Fig. 2). However genetic studies are necessary to determine the somaclonal variation. Genomic changes have been reported in A. tequilana Weber not only in micropropagated plants, but also in those propagated through natural asexual processes 
(Torres-Morán et al. 2010). Asexual genetic variability has also been reported in A. fourcroydes (Infante et al. 2003) and A. cupreata Trel et Berger (Martínez-Palacios et al. 2011). Another important aspect is to check the regenerative ability of callus tissues through time as has been reported in Sansevieria cylindrica Bojer ex Hook. (Shahzad et al. 2009).

\section{CONCLUSION}

It was found that the micropropagation of Agave americana through indirect organogenesis is feasible. The maximum percent of callus induction was obtained with $2.26 \mu \mathrm{M} 2,4-$ $\mathrm{D}$ and $11.0 \mu \mathrm{M}$ BA. Maximum number of shoots per explant was obtained with 0.11 of 2,4-D and $44 \mu \mathrm{M}$ BA after 36 weeks. Root number, root length and axillary roots were not affected by the concentration of IBA.

\section{ACKNOWLEDGEMENTS}

The research was funded by Comiteco Balun Canan S. de R. L. de C. V. Project 154047 "Innovación tecnológica para la reproducción, establecimiento, producción y aprovechamiento integral del agave comiteco". This research was supported by Project 'Infraestructura 251805' 'Consejo Nacional de Ciencia y Tecnología' (CONACyT, Mexico).

\section{REFERENCES}

Aviles Viñas, S., C.A. Lecona Guzmán, A. Canto Flick, E. Lopez Erosa \& N. SAntana Buzzy. 2012. Morpho-histological and ultrastructural study on direct somatic embryogenesis of Capsicum chinense Jacq. in liquid medium. Plant Biotechnology Reports 7(3): 277-286.

Bezerra, M.A., R.E. Santelli, E.P. Oliveira, L.S. Villar \& L.A. EsCALEIRA. 2008. Response surface methodology (rsm) as a tool for optimization in analytical chemistry. Talanta 76(5): 965-977.

Binh, L.T., L.T. Muoi, H.T.K. OAnh, T.D. Thang \& D.T. Phong. 1990. Rapid propagation of Agave by in vitro tissue culture. Plant Cell, Tissue and Organ Culture 23: 67-70.

Castro Concha, L., V.M. Loyola Vargas, J.L. Chan \& M.L. RoBert. 1990. Glutamate dehydrogenase activity in normal and vitrified plants of Agave tequilana Weber propagated in vitro. Plant Cell, Tissue and Organ Culture 22: 147-151.

Chen, Y., X. Chen, F. Hu, H. Yang, L. Yue, R.N. Trigiano \& Z.M. Cheng. 2014. Micropropagation of Agave americana. HortScience 49(3): 320-327.

Gaj, M.D., S.B. Zhang, J.J. Harada \& P.G. Lemaux. 2005. Leafy cotyledon genes are essential for induction of somatic embryogenesis of Arabidopsis. Planta 222(6): 977-988.

Garriga, C.M., O.G. González, G.S. Alemán, C.E. Abreu, B.K. Quiroz, P.D.S. Caligari \& R. García-González. 2010. Management of auxin-cytokinin interactions to improve micropropagation protocol of henequen (Agave fourcroydes Lem). Chilean Journal of Agricultural Research 70(4): 545-551.

Hamissa, A.M.B., F. Brouers, B. Mahjoub \& M. Seffen. 2007 Adsorption of textile dyes using Agave americana (L.) fibres: Equilibrium and kinetics modelling. Adsorption and Science Technology 25(5): 311-325.

Hazra, S.H., S. DAS \& A.K. DAs. 2002. Sisal plant regeneration via organogenesis. Plant Cell, Tissue and Organ Culture 70: $235-240$.

Illsley, C., A. Tlacotempa, G. Rivera, P. Morales, J. García \& T. Gómez. 2004. Manejo campesino de magueyes mezcaleros silvestres. México. Comisión nacional para el conocimiento y uso de la biodiversidad (CONABIO) 1 (1), pp. 34-45.

Infante, D., G. GonzÁlez, L. Peraza-Echeverría \& M. KebLlanes. 2003. Asexual genetic variability in Agave fourcroydes. Plant Science 164(2): 223-230.

Jian Ming, J., L. Xi KuI \& Y. Chong Ren. 2003. Three new hecogenin glycosides from fermented leaves of Agave americana. Journal of Asian Natural Products Research 5(2): 95-103.

Martínez Palacios, A., M.P. Ortega Larrocea, V.M. Chávez \& B. RoBert. 2003. Somatic embryogenesis and organogenesis of Agave victoriae-reginae: consideration for its conservation. Plant Cell, Tissue and Organ Culture 74: 135-142.

Martínez Palacios, A., J.M. Gómez Sierra, C. Sáenz Romero, N. Pérez Nasser \& N. SÁnchez Vargas. 2011. Genetic diversity of Agave cupreata Trel. \& Berger. considerations for its conservation. Revista Fitotecnia Mexicana 34(3): 159-65.

Meratan, A.A., S.M. Ghaffari \& V. Niknam. 2009. In vitro organogenesis and antioxidant enzymes activity in Acanthophyllum sordidum. Biologia Plantarum 53(1): 5-10.

Murashige, T. \& F. Skoog. 1962. A revised medium for rapid growth and bioassays with tobacco tissue cultures. Physiologia Plantarum 15(3): 473-497.

Nasri, S. \& H. Ben Salem. 2012. Effect of oral administration of Agave americana or Quillaja saponaria extracts on digestion and growth of Barbarine female lamb. Livestock Science 147(1): 59-65.

NIKAM, T.D. 1997. High frequency shoot regeneration in Agave sisalana. Plant Cell, Tissue and Organ Culture 51: 225228.

Nikam, T.D., G.M. Bansude \& K.C. Aneesh Kumar. 2003. Somatic embryogenesis in sisal (A. sisalana Perr. ex. Engelm). Plant Cell Reports 22(3): 188-194.

Pan, Z., R. Guan, S. Zhu \& X. Deng. 2009. Proteomic analysis of somatic embryogenesis in Valencia sweet orange (Citrus sinensis Osbeck). Physiology and Biochemistry 29(2): 281-289.

Portillo, L., F. Santacruz Ruvalcaba, A. Gutiérrez Mora \& B. Rodríguez Garay. 2007. Somatic embryogenesis in Agave tequilana Weber cultivar azul. In Vitro Cellular \& Developmental Biology - Plant 43: 569-575.

Robert, M.L., J.L. Herrera, F. Contreras \& K.N. Scorer. 1987. In vitro propagation of Agave fourcroydes Lem. (Henequen). Plant Cell, Tissue and Organ Culture 8: 37-48.

Robert, M.L., J.L. Herrera, J.L. Chan \& F. Contreras. 1992. 
Micropropagation of Agave spp. In: Y.P.S. Bajaj (ed.), Biotechnology in agriculture and forestry, Vol 19. Hightech and micropropagation III, pp. 307-329. SpringerVerlag, Berlin, Germany.

Rocha, M., A. Valera \& L.E. Eguiarte. 2005. Reproductive ecology of five sympatric Agave littaea (Agavaceae) species in central Mexico. American Journal of Botany 92(8): 1330-1341.

Rodríguez Garay, B., A. Gutiérrez \& B. Acosta Dueñas. 1996. Somatic embryogenesis of Agave victoriae-reginae Moore. Plant Cell, Tissue and Organ Culture 46: 85-87.

Santacruz Ruvalcaba, F., H. Gutiérrez \& B. Rodríguez. 1999. Efficient in vitro propagation of Agave parrasana Berger. Plant Cell, Tissue and Organ Culture 6(3):164-167.

Shahzad, A., N. Ahmad, , M.A. Rather, M.K. Husain \& M. Anis. 2009. Improved shoot regeneration system through leaf derived callus and nodule culture of Sansevieria cylindrica. Biologia Plantarum 53(4): 745-749.

Santana-Buzzy, N., G. Lopez-Puc, A. Canto-Flick, F. BarredoPool, E. Balam-Uc, S. Aviles-Viñas, D. Solís-Marroquín, C. Lecona-Guzman, J. Bello-Bello, E. Gomez-Uc \& J.O. Mijangos-Cortes. 2009. Ontogenesis of the somatic embryogenesis of Habanero pepper (Capsicum chinense Jacq.). HortScience 44(1): 113-118.
SAS, Institute. 1990. Statistic Guide for Personal Computers. Version 6.04, Edn. SAS Institute. Cary, pp. 1-102.

Tinto, W.F., J.L. Simmons Boyce, S. McLean \& W.F. Reynolds. 2005. Constituents of Agave americana and Agave barbadensis. Fitoterapia 76(6): 594-597.

Torres Morán, M.I., M. Escoto Delgadillo, S. Molina Moret, D.M. Rivera Rodríguez, A.P. Velasco Ramírez, D. Infante \& L. Portillo. 2010. Assessment of genetic fidelity among Agave tequilana plants propagated asexually via rhizomes versus in vitro culture. Plant Cell Tissue and Organ Culture 103(3): 403-409.

Zapata Castillo, Y.P., A. Canto Flick, G. López Puc, A. Solís Ruiz, F. Barahona Pérez \& N. Santana Buzzy. 2007. Somatic Embryogenesis in Habanero Pepper (C. chinense Jacq.) from cell suspensions. HortScience 42(2): 1-5.

Zhang, C.L., D.F. Chen, C.E. Malcolm \& A. Slater. 2004. Efficient procedures for callus induction and adventitious shoot organogenesis in sugar beet (Beta vulgaris L.) breeding lines. In Vitro Cellular and Developmental Biology - Plant 40(5): 475-481.

Zuo, J., Q.W. Niu, G. Frugis \& N.H. ChuA. 2002. The WUSCHEL gene promotes vegetative-to-embryonic transition in Arabidopsis. The Plant Journal 30(3): 349-359.

Recibido: 08.07.13

Aceptado: 06.05.16 